\title{
Injury mortality in Sweden; changes over time and the effect of age and injury mechanism
}

\author{
Denise Bäckström
}

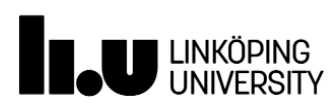

Faculty of Medicine and Health Sciences

Department of Clinical and Experimental Medicine (IKE)

1 December 2017 
(C) Denise Bäckström, 2017

Printed by LIU-Tryck, Linköping, Sweden, 2017.

Previously published articles (paper I and II) have been reprinted with the permission of the copyright holders.

ISBN: 978-91-7685-411-2

ISSN: 0345-0082 
Injury mortality in Sweden; changes over time and the effect of age and injury mechanism

Denise Bäckström

To Wilhelm, Waldemar, Widar and Ofelia

Pergite! 


\section{Supervisor}

Folke Sjöberg, MD, PhD, Professor

Department of Clinical and Experimental Medicine

Faculty of Medicine and Health Sciences

Linköping University, Sweden

\section{Opponent}

Lovisa Strömmer, MD, PhD, Associate Professor

Department of Clinical Science, Intervention and Technology

Faculty of Medicine

Karolinska Institutet, Sweden

\section{Committee board}

Ola Wahlström, Professor Emeritus

Department of Clinical and Experimental Medicine

Faculty of Medicine and Health Sciences

Linköping University, Sweden

Eldar Söreide, MD, PhD, Professor

Department of Clinical Medicine

Faculty of Medicine

University of Bergen, Norway

Oliver Gimm MD, PhD, Professor

Department of Clinical and Experimental Medicine

Faculty of Medicine and Health Sciences

Linköping University, Sweden 


\section{CONTENTS}

CONTENTS

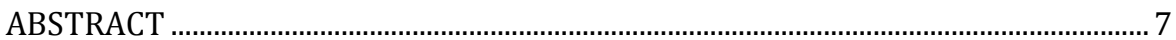

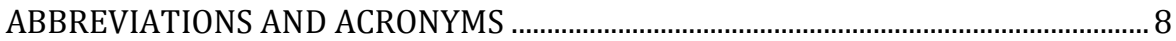

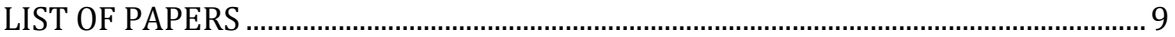

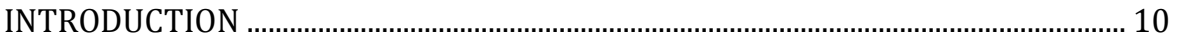

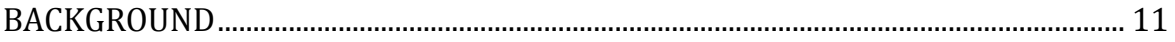

Injury

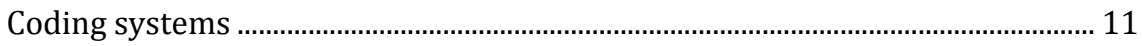

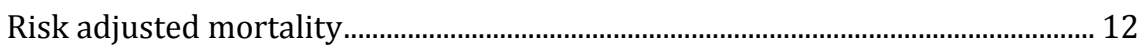

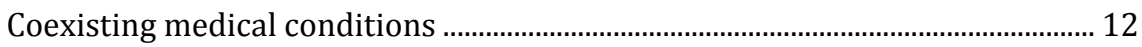

Mortality in different age groups ............................................................................. 12

Injury mechanism in different age groups .............................................................. 13

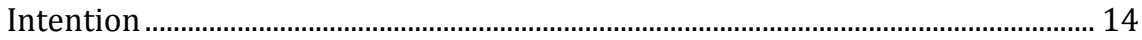

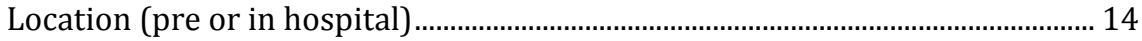

Trauma organisation, trauma hospital systems...................................................... 15

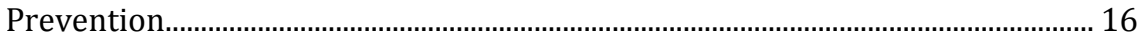

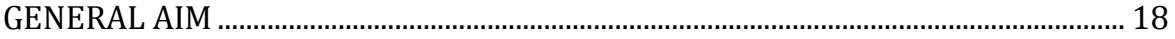

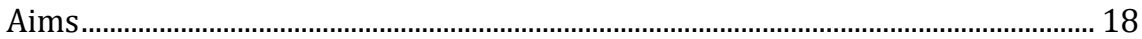

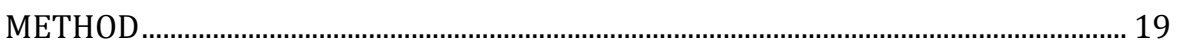

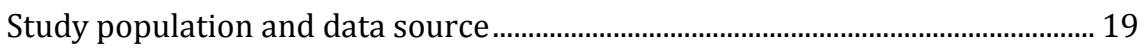

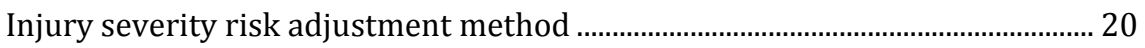

Calculations of incidence and coexisting medical conditions ............................... 20

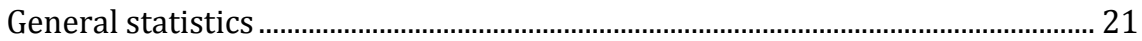

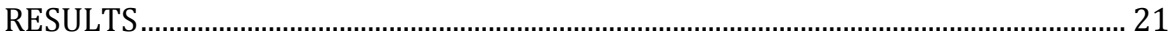

Injury-related mortality in different ages over time .............................................. 21

Injury related mortality in different injury mechanisms over time ..................... 24

Injury related mortality changes depicted over time by injury mechanisms and

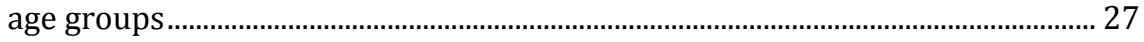

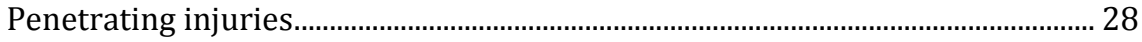

The effect of intention on injury mortality ............................................................... 28

Injury mortality and the effect of location (pre or in hospital) ............................. 29

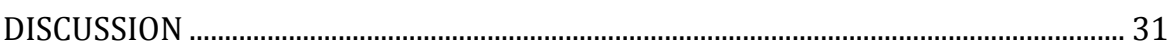

Injury-related mortality in different age groups over time................................... 31

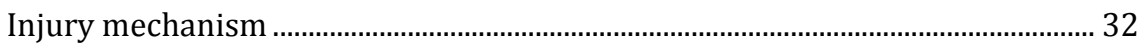

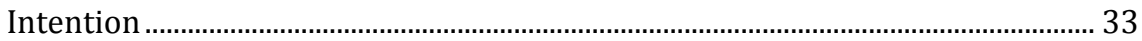




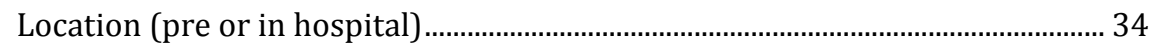

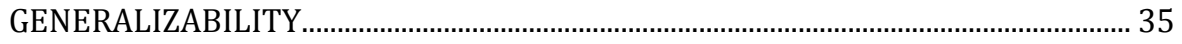

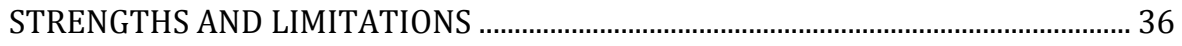

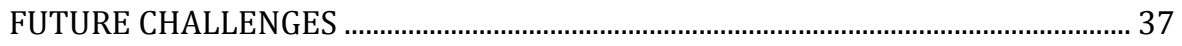

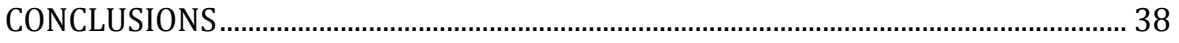

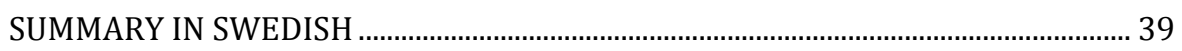

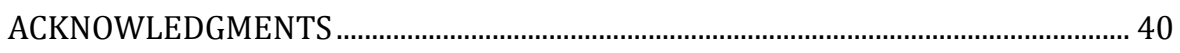

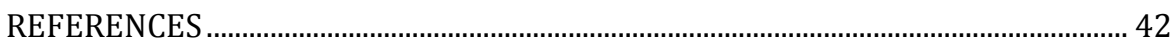




\section{ABSTRACT}

Background: Injuries are one of the most common causes of death in the world. Varying types of injuries dominate in different parts of the world, which also have separate influences on mortality. In Scandinavia blunt injuries dominates and the majority of those who die do so pre hospital. Over time different injury pattern may vary and by analyzing this we can assess when, where and how preventive work can be reinforced. The aim of this thesis was to study injury epidemiology in Sweden and assess the contribution of different injury patters on mortality.

Method: We used the Swedish cause of death and the national patient registries which have a complete national coverage. The international classification of disease injury severity score (ICISS) was calculated (based on ICD-10) in the in hospital population. We have chosen to do this investigation with a broad perspective using the term injury, which includes trauma but also other diagnoses like suffocation and drowning.

Results: During the study period (1999-2012) the number of deaths because of injury was 1213, 25 388, and 18332 among children, working age and elderly, respectively. Mortality declined in the children and in the working age but inclined in the elderly. Mortality increased with each age group except between the ages of 15-25 and 26-35 years. One thousand two hundred sixty four (97\%) of those who died because of penetrating trauma (sharp objects and firearms) were killed by intentional trauma (assault and intentional self-harm). One thousand and seventeen (83\%) of the children died prehospital. In the working age 22211 (80\%) of 25388 died pre hospital. Nine thousand six hundred and eighteen (53\%) of 18332 of the elderly died prehospital. During 2001-2011 the risk adjusted in hospital mortality decreased in traffic and assault but not in fall related injuries.

Discussion: Largely, the anticipated injury mortality picture was found, with blunt injuries (traffic accidents) dominating in the working age and falls in elderly. Further a significant portion of the deaths occurred pre hospital. The intentional injuries are dominated by intentional self-harm. The decrease in child injury mortality is notable as Sweden already has one of the lowest incidences in child injury mortality in the world. The decrease in injury mortality in the working age also implies that preventive work has had an effect. The incline in injury mortality in elderly on the other hand needs to be further studied. Areas of particular importance for future preventive work is the incline in injury mortality in elderly and intentional injuries among children. 


\section{ABBREVIATIONS AND ACRONYMS}

$\begin{array}{ll}\text { ATLS } & \text { Advanced trauma life support } \\ \text { CCI } & \text { Charlson comorbidity index } \\ \text { CDR } & \text { Cause of death registry } \\ \text { CI } & \text { Confidence interval } \\ \text { DSP } & \text { Diagnosis specific survival probability } \\ \text { EMS } & \text { Emergency medical services } \\ \text { ICD-10 } & \text { International classification of diseases - tenth revision } \\ \text { ICISS } & \text { International classification of disease injury severity score } \\ \text { ISS } & \text { Injury severity score } \\ \text { NAEMT } & \text { National association of emergency medical technicians } \\ \text { NPR } & \text { National patient registry } \\ \text { PHTLS } & \text { Prehospital trauma life support } \\ \text { PIN } & \text { Personal identification number } \\ \text { WHO } & \text { World health organisation }\end{array}$




\section{LIST OF PAPERS}

Bäckström D, Steinvall I, Sjöberg F. Change in child mortality patterns after injuries in Sweden: a nationwide 14-year study. Eur J Trauma Emerg Surg 2017;43:343-9.

Bäckström D, Larsen R, Steinvall I, Fredrikson M, Gedeborg R, Sjöberg F. Deaths caused by injury among people of working age (18-64) are decreasing, while those among older people (64+) are increasing. Eur J Trauma Emerg Surg 2017 (in Press).

Larsen R, Bäckström D, Fredrikson M, Steinvall I, Gedeborg R, Sjöberg F. Decreased risk adjusted 30-day mortality for hospital admitted injuries - a multicentre longitudinal study. Submitted/under revision

Bäckström D, Larsen R, Steinvall I, Fredrikson M, Gedeborg R, Sjöberg F. Decline in mortality from firearms and sharp objects during a 14-year period (1999-2012) in Sweden. Submitted. 


\section{INTRODUCTION}

Injury is; damage to the body caused by an external force, thus it is the surrounding interacting with the human body causing tissue damage and not an internal process in the body. Injuries causes considerable suffering around the world and is a common cause of morbidity and mortality in all ages worldwide (1, 2).

In order to address the burden of injuries we first of all need to know what it looks like. Injuries are a consequence of the environment we live in and over time this changes. The changes in injury mortality can help guide us to where preventive work needs to be reinforced or if health care needs to focus in different fields.

This thesis is based on four studies focusing on injury mortality and based on national registries with epidemiological data. Study I investigates the differences in child injury mortality between unintentional and intentional injuries. We analyse both injury mechanism and mortality mechanism and the trend over time. In study II we investigate injury mortality in the working age 18-64 and the elderly, 65 years and older, and how it has changed over time. In study III we have investigated the risk adjusted in-hospital trauma mortality in the three most lethal trauma mechanisms, traffic, fall and assault. The focus of study IV is on penetrating trauma, investigating the mortality trend over time in firearm and sharp objects. 


\section{BACKGROUND}

\section{Injury}

In this thesis both the term injury and trauma are used. Injury is the broader term, including trauma but also other types of injury such as drowning and suffocation. The term trauma usually only includes diagnoses that traditionally have a surgical connection, although there is no universal consensus on which diagnoses that should be included. One diagnosis that is usually excluded from trauma studies is burns, most likely because burns usually are not included in most trauma registries.

Falls are also a debated diagnosis where falls from heights usually are considered trauma while falls in the same level often are excluded from trauma studies although they have been shown to significantly contribute to trauma mortality (3). This is an important detail for the reader to be aware of as conclusions based on trauma subgroups in such studies could misguide the reader.

In this thesis two of the studies (I, II) have an injury and two studies (III, IV) a trauma perspective. The reason why we chose the injury perspective was because we wanted to give a complete coverage of the Swedish injury/trauma situation and thus not exclude diagnoses but rather have an inclusive approach. In the European Union more than 40 million people are treated in hospitals each year because of injuries to an estimated cost of 78 billion Euro(1). This of course has a huge impact on both society and the lives of the people affected.

In Scandinavia the numbers of severe trauma (Injury Severity Score, ISS $>15$ ) is between 30 and 54 per 100000 inhabitants per year $(4,5)$. The trauma picture in Sweden is similar to the rest of Scandinavia which is a result of the similar medical organisations and living situations (4). In Sweden approximately 4500 people die each year because of injuries, both intentional and unintentional (6). In Sweden, $7 \%$ of all deaths are caused by injuries (1).

\section{Coding systems}

Sweden has a unique personal identification number (PIN) for every person living in the country. The number is organized and handed out by the Swedish Tax Agency (7). We have used the PIN to link different databases so that they are connected on an individual level. The identification number allows an almost $100 \%$ coverage of the health care system in Sweden (8).

Since 1948 the World health organisation has been in charge of the International classification of disease (ICD) system. It has existed for about one hundred years and has been revised ten times. The purpose of the ICD is to enable classification 
of diseases and health issues in order to analyse, interpret, and compare morbidity and mortality data (9). The ICD-10 diagnosis is decided by the physician in charge of the patient, sometimes after an autopsy. Patients who die before reaching hospital most often undergo a forensic examination and in such cases the forensic examiner decides the ICD-10 coding.

\section{Risk adjusted mortality}

The ISS method has long been regarded as the injury severity coding standard for evaluating trauma in research settings (10) and clinical measurements. The method is, however, limited as it requires that all patients are recorded in specialised trauma registry.

In 1996 Osler et al. developed a new score, the International Classification of diseases Injury Severity Score (ICISS), to be able to use big databases of existing codes which are recorded for administrative purposes (11). The ICISS has been found to be a better mortality predictor than the previously most used method (ISS) (12) and it allows an accurate estimate of injury severity (13). The ICISS is a valuable tool for trauma research as it allows risk adjusted mortality prediction in administrative registries.

\section{Coexisting medical conditions}

Pre-existing medical conditions are associated with increased mortality after trauma. This effect has been shown to be both independent and additive to the effect of age $(14,15)$. When assessing injury or trauma patient mortality it is important to be able to discriminate in what has caused the death. If we only look at the injury mechanism we can be misled to believe that falls in the same plane is highly lethal since they actually result in a high numbers of deaths. But when adding the coexisting medical conditions to the analysis we get a more nuanced picture with the coexisting medical condition contributing to the mortality.

The Charlson Comorbidity Index (CCI) (16) is a mortality prediction method to classify pre-existing medical conditions based on ICD diagnoses from administrative data (17). A score of zero indicates no pre-existing medical condition, the higher score, the more severe and/or higher number of co-existing medical conditions. The CCI has been found to be of value also in predicting mortality in trauma patients (18).

\section{Mortality in different age groups}

In the whole world it has been estimated that 830000 children (under the age of 18) die because of unintentional injuries each year (19). There has been a decline 
in child injury mortality in the wealthy countries, but there is still need for further improvements (19). Finland has a child injury mortality of 5 per 100000 (20).

In Sweden 135000 children are admitted to hospitals each year because of injuries (6). Death caused by injuries is the leading cause of death for children in Sweden, although the Swedish numbers are among the lowest in the world $(6,21)$. Injuries are most likely the most common cause of death because other causes of death like, cancer and infections has been prevented or treated with better results (22). The decline in child injury mortality has also been explained by favourable economic and social conditions (23).

The working age is quantitatively the largest injury group, yet few studies have had this focus $(24,25)$. In Norway the country mortality rate has been found to be 30 per 100000 during the years 1998-2007(26). The lack of epidemiological injury statistics in e.g., the working age has been a driving force in the development of this thesis.

Injury mortality in elderly is a growing problem in the western world with an aging population $(4,27-29)$. The aging population causes an increased burden on the healthcare system $(27,28)$. Injury mortality seems to increase with older age (14-18) but the reason for the higher mortality in older ages is complex, it does not seem to be an effect of nor age or comorbidities alone (29).

\section{Injury mechanism in different age groups}

Different types of injury dominates in varying parts the world. This also has an impact on injury mortality as mortality varies due to different injury mechanisms (2). In North America penetrating injuries usually dominate, mainly because of firearm injuries $(30,31)$. Europe has an injury pattern where blunt injuries dominate mainly because of traffic accidents (32). In Scandinavia blunt injury is dominating the injury pattern with figures as high as $85-90 \%(4,33)$.

Vehicle related injuries are responsible for a large number of deaths worldwide. In Sweden there has been a decline in traffic accidents during the last decade but since 2002 this decline seems to have levelled off (6). Intentional self-harm is another common injury mechanism in Sweden (34). Sports and vigorous exercise has also been shown to contribute to morbidity and mortality (35).

Blunt injuries dominate in children, they make up between $83-92 \%(20,36)$ of all injuries, and road traffic accidents is the most common cause $(36,37)$. During the first years in life the unintentional injuries are the most common and during the teenage years intentional self-harm increases and becomes the second most common cause of death (22). 
With an older population there will be more elderly people active in the society and, also as a consequence, more elderly people get injured. The most dominating injury mechanism among elderly is fall (27-29). The numbers of penetrating injuries among elderly seems to be low (29) and decrease with increasing age (27).

\section{Intention}

In the ICD-10 system intention is also included in the registrations. Assault and intentional self-harm are classified as intentional, some diagnoses are classified as intention unknown and some as unintentional. The unintentional group is the largest and includes for example traffic and falls.

The physician in charge of the patient registers the ICD-10 diagnosis. This is of course done to the best of the ability of that physician but the intent is often difficult to assess. Sometimes intentional self-harm is evident but there can be cases where there is a suspicion of self-harm but no real proof. This will of course lead a significant risk for miscoding but to what extent is not known today.

In Sweden 120000 people are admitted to hospitals annually because of unintentional injuries (22). Among the children death from injuries have been declining since the 70-ties but the decline seems to have levelled off recently, (6, $23,38)$. Unintentional injuries is dominating and represents more than $90 \%$ of all injuries among children (39). It has been estimated that $35 \%$ of the unintentional injuries in the working age group (18-64) could potentially be prevented (21). Intentional trauma mortality (self-harm and assault) has been found to be higher in areas with higher numbers of inhabitants (26).

\section{Location (pre or in hospital)}

Saving lives after a trauma is often a race against time as most deaths occur early after injury $(33,34,40)$. Trunkey (41) first described the tri-modal death distribution with the first peak occurring within seconds to minutes, caused by un-salvable injuries best treated by preventive work. The second peak occurs within minutes to hours, this peak is interesting as it is this group of patients that would benefit most from an effective trauma treatment and a well-functioning trauma care system. The third peak occurs after days to weeks after injury and is characterized by death caused by complications to the trauma. This model has been taught to physicians worldwide through the ATLS course, and the knowledge of this concept is widely spread. During the years the model has been questioned $(31,42)$ and it is no longer considered a valid scientific concept although it has educational advantages, which probably is the reason why it still is being taught. 
The time to hospital has also been found to be a good mortality predictor in trauma patients, where longer time to hospital leads to a higher mortality (43). This is also evident when patients with firearm injuries have a better chance of survival if they are transported to hospital by civilians instead of EMS (44). Transport time and the resulting pre hospital death rates also influences the in hospital death rates as some of the people arriving fast will die early in the hospital. Patients with long transport times are more likely to die pre hospital and thus the in hospital mortality will be lower and give a false impression of high quality care system with the following low mortality numbers. This is one reason why in hospital mortality should be analysed together with pre hospital mortality.

Different trauma mechanisms contribute differently to pre hospital trauma deaths, the highest is seen in the self-harm group with a $89 \%$ pre hospital mortality. The corresponding numbers for transport and falls are $75 \%$ and $51 \%$, respectively (26).

Long distances and a difficult climate makes the prehospital management in Scandinavia a challenge. Time to reach the hospital is long, and patients requiring treatment at specialized clinics have even longer transport times (45). The rural setting with delayed incident reporting, long transport times and more lethal injury mechanism $(5,46)$ are factors that have been used to explain the high numbers of prehospital deaths in Scandinavia. It has been reported to be in the range of $45-85 \%(26,33,34,40,47)$. Trauma data in the pre hospital setting differs to that in hospital, with more men dying and at a lower age $(33,34)$.

Depending on age, children get injured in different places. The youngest get hurt in or around the home, and between the ages of 7-12 the sites where the injury occurs are distributed evenly between the home and sports and athletic grounds. In older age groups most of the injuries happen on the sports and athletic fields, and in older age on the roads (6). The pre hospital child injury mortality is in the range of 54 and $58 \%$ in Scandinavia $(20,36)$.The majority of deaths in the working age is located in the pre hospital setting, in Norway $78 \%$ has been found to die in the pre hospital setting in the years between 1998 and 2007(26). In the group of elderly in hospital death is more common (34).

\section{Trauma organisation, trauma hospital systems}

The public emergency number in Sweden is 112. When calling you will reach the government financed dispatch organisation SOS alarm that will dispatch the ambulances (48). 
The prehospital emergency medical services (EMS) is organised and funded by the county councils in Sweden. Ambulances are manned by two people where at least one of them is a nurse. There is a university specialist training for ambulance nurses but specialist training in anaesthesia is usually acceptable too.

Patients are usually transported to the nearest hospital and if they need specialist treatment they are subsequently transported to a larger hospital. At the hospital's trauma patients are treated according to the advanced trauma life support (ATLS). There are no trauma surgeons in Sweden, mostly because there are too few trauma cases to keep them busy. The surgeon caring for the trauma patient is usually a general surgeon, but it can also be a specialized surgeon like a neurosurgeon if the patient has isolated head injuries.

Sweden has an EMS system based on ground transport. During the study period there were few helicopters and also few physicians working in the pre hospital setting. The other Scandinavian countries have a tradition of physicians' pre hospital, and in Norway and Finland also helicopters (4).

There is presently no national organized trauma system in Sweden. The need for this has been addressed and there is ongoing work on this topic (49). The need for an organized trauma system has also been identified previously in other countries $(50,51)$.

After a personal tragedy where his family was severely injured, Dr Jim Styner started the advanced trauma life support training (ATLS) and the first course was held in in 1978. The course is now a foundation in trauma care in hospitals and provides the participants with a common approach and language in the care of injured patients (52). The first course in Sweden was held in 1996 and since then the course has been revised several times and at the moment it is under the $9^{\text {th }}$ edition (53). ATLS is now an implemented approach to trauma in Sweden.

American college of surgeons and National association of emergency medical technicians (NAEMT) developed prehospital trauma life support (PHTLS) in 1983. The first course in Sweden was held in 1998. The aim of this course is to reduce trauma morbidity and mortality and ensure an adequate treatment of trauma patients in the prehospital setting (54).

\section{Prevention}

A number of the pre hospital deaths occur immediate as the patients are severely injured $(33,34)$ and thus un-salvable. The only way lower these numbers would be preventive work. This is why we think that many of our findings reflect the 
preventive work that has been done in society and this information may also contribute to further preventive work.

Traffic and transport related injuries is one of the major injury mechanisms in the world $(2,32,33)$. Sweden has had declining numbers for several years (6) and has an ongoing campaign since 20 years, the so called "Zero policy" under the direction of "The Swedish transport administration". The campaign focuses on a preventive work with the aim that no one should die or get injured in traffic. So far the "Zero policy" has managed to reduce the mortality in traffic with about 50\%. The participation in day-care activities for children seems to have a preventive effect on child injury mortality as well as mandatory swimming lessons (38). 


\section{GENERAL AIM}

Although trauma is a leading cause of death it has not received the same amount of attention research wise. In Sweden there is a unique situation for epidemiological studies with the almost complete national coverage in government financed patient registries. In this aspect the registries have been found valid for epidemiological studies especially as ICD-10 diagnoses of injury and causes of injury are included (34).

The general aim of this research project was to study injury epidemiology in Sweden and assess the contribution of various effects on mortality.

\section{Aims}

To investigate:

i) injury-related mortality in different age groups during the study period

ii) injury-related mortality due to different injury mechanisms during this period

iii) the effect of intent on injury mortality

iv) injury mortality and where the death occurred (pre or in hospital) 


\section{METHOD}

\section{Study population and data source}

The study period was a 14-year period from $1^{\text {st }}$ January 1999 to 31 st December 2012 for the studies of injury related deaths, including pre hospital mortality (Paper I, II, IV) and a 10-year period from 2001 to 2011 for the study focusing on in hospital mortality prediction (Paper III), the latter including both the patients who survived and those who died after injury. We used the Swedish cause of death registry (CDR) where every Swedish citizen is registered (55). All admissions to hospital and co-morbidities were gathered from the Swedish national patient registry (NPR) (56). Population data for the country were obtained from the Swedish population registry (57).

In Sweden all under the age of 18 are considered as children and thus treated at separate children wards/hospitals. There is no consensus concerning what is considered older age in the literature, we chose the age of 65 because it is the general retirement age in Sweden and we speculate that there is a significant behaviour change when people retire.

The injury population was collected from the CDR (Paper I, II, IV) and the NPR (Paper III). We identified those whose underlying cause of death was recorded as external causes of morbidity and mortality in the International Classification of Diseases, 10th Revision (ICD-10) (Table 1). We refer to the underlying cause of death as the "mechanism of injury".

Table 1. External causes of morbidity and mortality, ICD-10 codes used in the papers

\begin{tabular}{lllll}
\hline & Paper I & Paper II & Paper III & Paper IV \\
\hline Accidents, traffic & V01-V99 & V01-V99 & V01-V99 & \\
$\begin{array}{l}\text { Accidents, fall } \\
\text { Accidents }\end{array}$ & W00-W19 & W00-W19 & W00-W19 & \\
Accidents & W20-X49 & W20-X49 & & W26, W32 \\
$\begin{array}{l}\text { Intentional self-harm } \\
\text { Assault }\end{array}$ & X58-X59 & & & \\
$\begin{array}{l}\text { Xndetermined intent } \\
\text { Legal intervention }\end{array}$ & X85-Y09 & X85-Y09 & X85-Y09 & X93, X99 \\
and operations of war & & & & Y22, Y28 \\
\hline
\end{tabular}


Table 2. Overlap, number of patients.

\begin{tabular}{ccccc}
\hline Paper & I & II & III & IV \\
\hline I & 1213 & & $196^{*}$ & 38 \\
II & & 43720 & $11891^{*}$ & 1272 \\
III & & & $815846^{*}$ & $159^{*}$ \\
IV & & & & 1310 \\
\hline
\end{tabular}

The table is structured as a correlation table: the total number of patients included in each study are shown in the matrix position of one study; the overlap number of patients are shown in the matrix position of two studies. *Hospital admissions

In study I, II and IV we have included only the primary diagnosis as the cause of death, this excludes the late deaths caused by injury as they will not have an injury ICD code as a primary diagnosis. In study III we used 30-day mortality, the definition of mortality was death within 30 days of the index date. Death pre hospital was defined as death with no recorded hospital admission and death in hospital was defined as death with an admission date. The in hospital study population was selected to cover the three (fall, traffic, and assault) most lethal injury mechanisms among in hospital patients in Sweden (34). The overlap of patients between the studies is shown in Table 2 .

\section{Injury severity risk adjustment method}

The diagnosis specific survival probability (DSP) for calculating ICISS included all patients (ICD-10 V01-Y98.9 or S00-T80, excluding T78 (adverse effects), using one main diagnosis and up to nine subsequent diagnoses to reflect the added mortality of multi-trauma. The ICISS for individual injury cases in the study population was calculated as the product of each probability for survival for said injury (11). The ICISS-model was used to build a larger mortality model and also to include, sex, age, and study years.

\section{Calculations of incidence and coexisting medical conditions}

Population data from the Swedish population registry (57), were used for calculating the incidence of mortality after injury as deaths /100 000 personyears. The Charlson Comorbidity Index (CCI) was calculated using the scale as described in the original publication (16) and with the use of ICD-codes from Christensen et al. (17). 


\section{General statistics}

Differences between groups were tested with t test or chi-square test. Change over time was tested with linear regression. Multivariable logistic regression was used to analyse risk adjusted mortality. Probabilities of less than 0.05 were accepted as significant.

\section{RESULTS}

During the study period the number of deaths due to injury was 1213,25388 , and 18332 , in children, working age and among elderly, respectively.

\section{Injury-related mortality in different ages over time}

As shown in papers I-II mortality increased with each age group except between ages of 15-25 and 26-35 years (Figs. 1, 2). The incidence in child injury mortality increases more rapidly when the children are 13 years old and at the age of 17 the mortality is more than fourfold as high as at the of the ages 0-12 (Fig. 3).

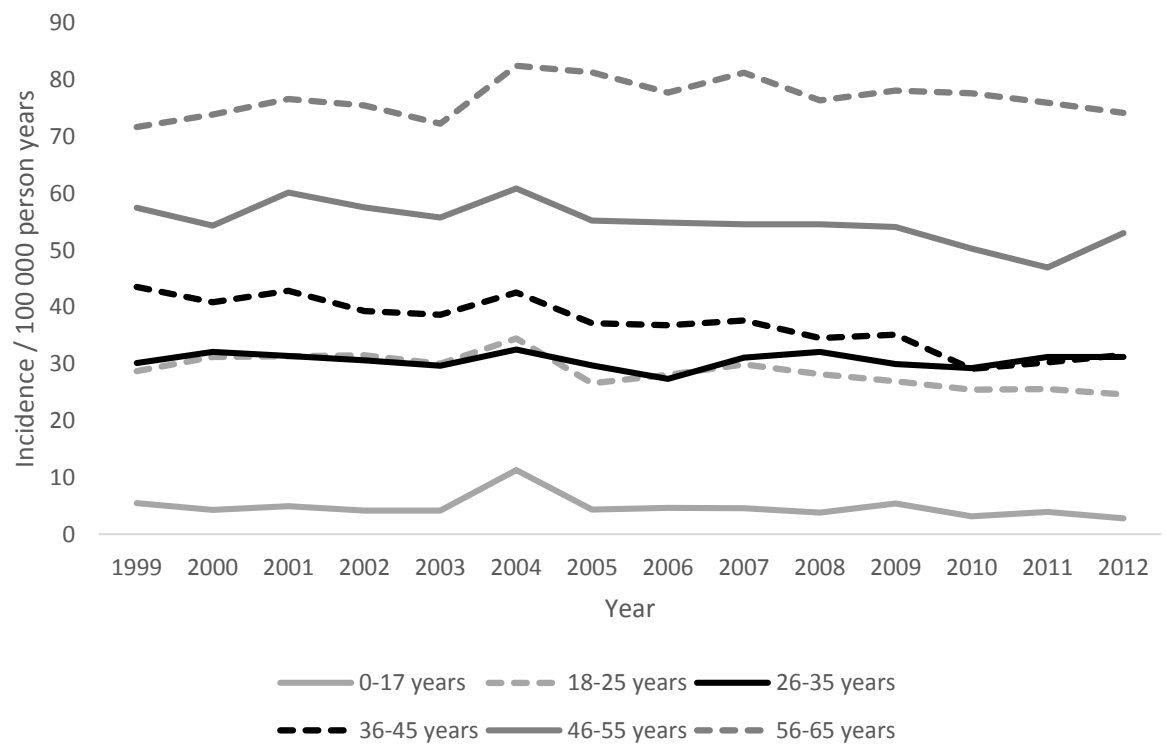

Fig. 1. Mortality/100 000 in age groups 0-65 years 


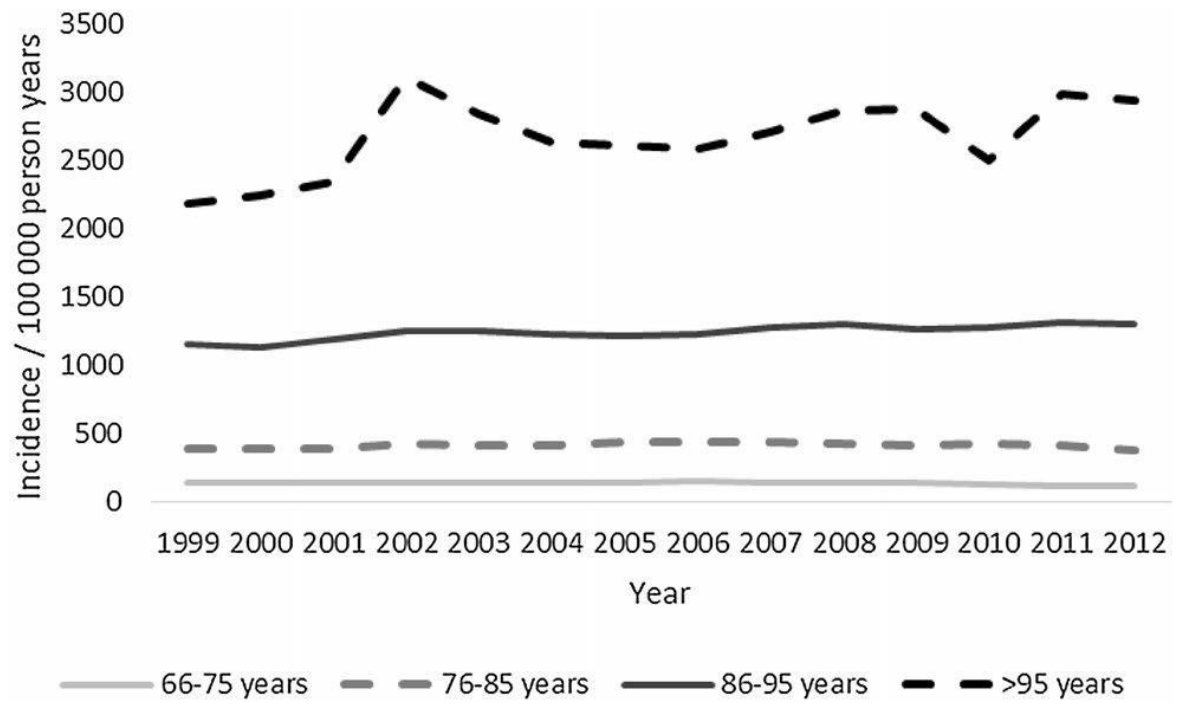

Fig. 2. Mortality/100 000 in age groups 66 years and older

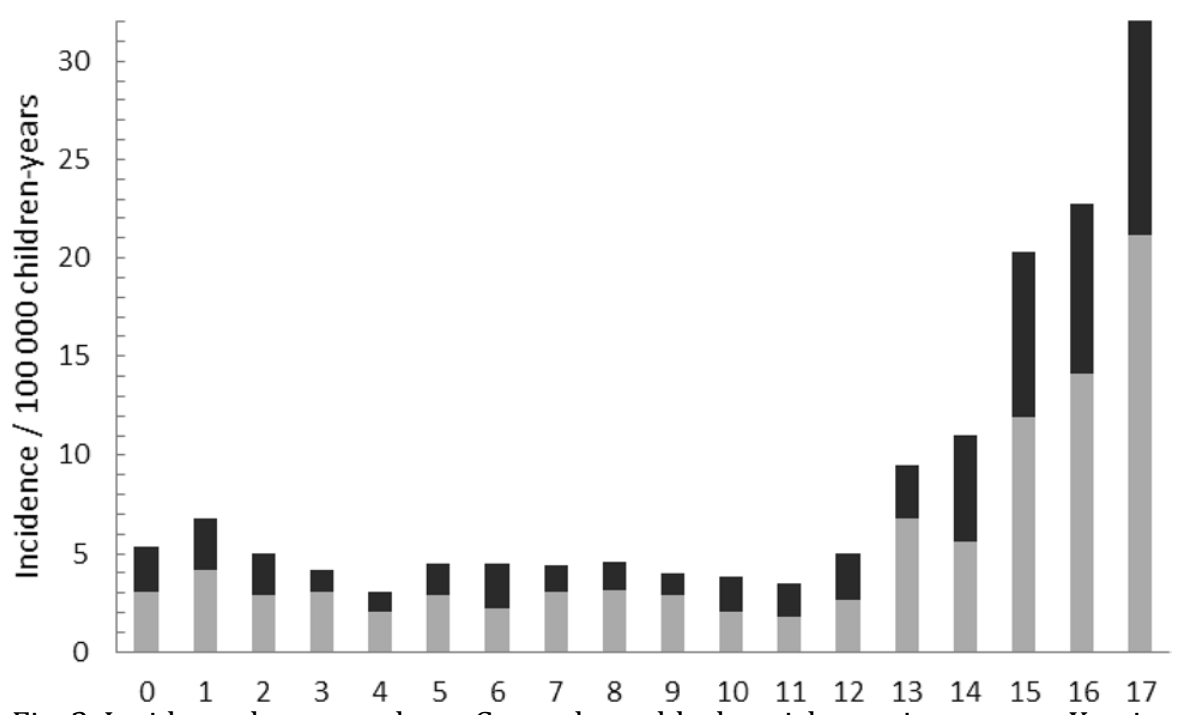

Fig. 3. Incidence by age and sex. Grey = boys, black = girls, age in years on X-axis

Injury mortality declined in the group of children (coefficient $-0.18, r^{2}=-0.37, p$ $=0.02$ ) (Fig. 4), mainly due to the decrease among boys (coefficient $-0.13, \mathrm{r}^{2}=$ 
$-0.48, p=0.006)$. Figure 1 shows the results from Study II and Figure 4 shows the results from study I, note inclusion was different between studies. In study I the children that died in the tsunami disaster in the Indian Ocean in 2004 (ICD-10 diagnosis X39) were excluded as outliers.

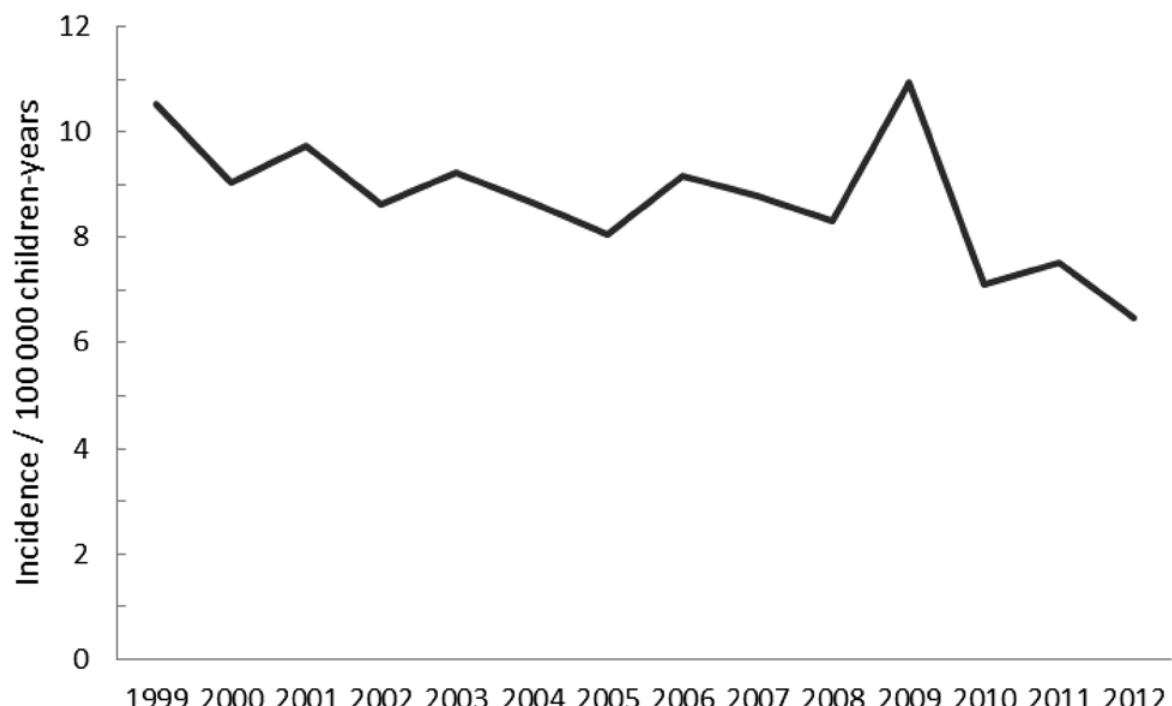
Fig. 4. Deaths from injuries among children, years on X-axis

Injury mortality over time declined in the group of working age (coefficient-0.40, $r^{2}=0.37 ; p=0.02$ ) (Fig. 5) but increased in elderly (simple linear regression showed that for each year the mortality increased with $0.59 / 100000$ personyears, $p=0.046$ ). When the model was adjusted for age (the coefficient for the variable "age" was -3.6 and not significant), the increase in adjusted incidence due to age was $1.39 / 100000$ person years $(p=0.03)$. As age was not found to influence the regression the increase in mortality does not seem to be an effect of an older population. 


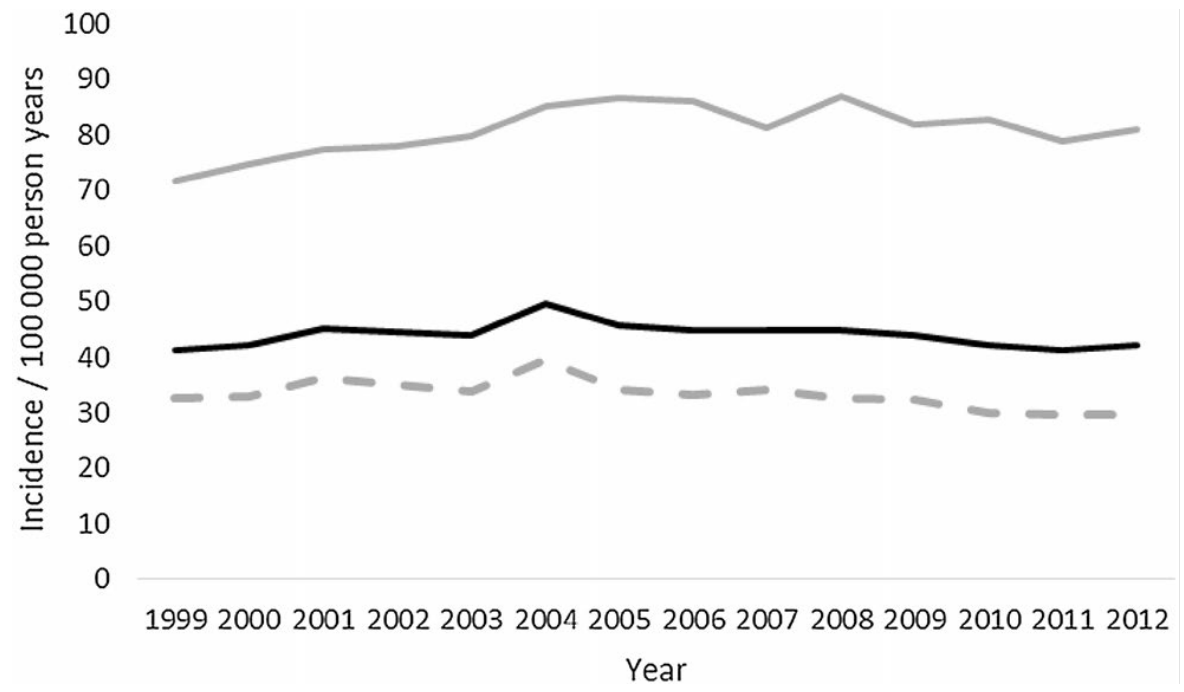

Fig. 5. Mortality/100 000 by year. Black all adults (over 17 years), grey elderly, dotted grey working age

Injury related mortality in different injury mechanisms over time

The proportional distribution of deaths in different injury mechanisms was not the same among the three age groups (Fig. 6) 
Injury mortality in Sweden; changes over time and the effect of age and injury mechanism

Denise Bäckström

\section{Children $<18$ years}

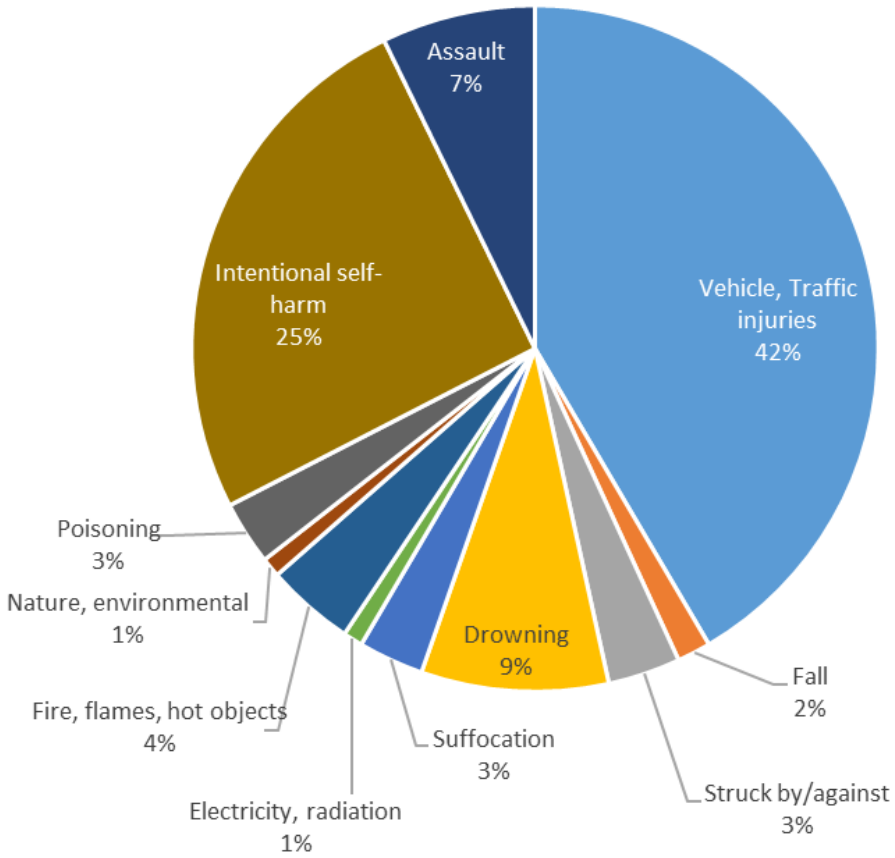


Working age 18-64

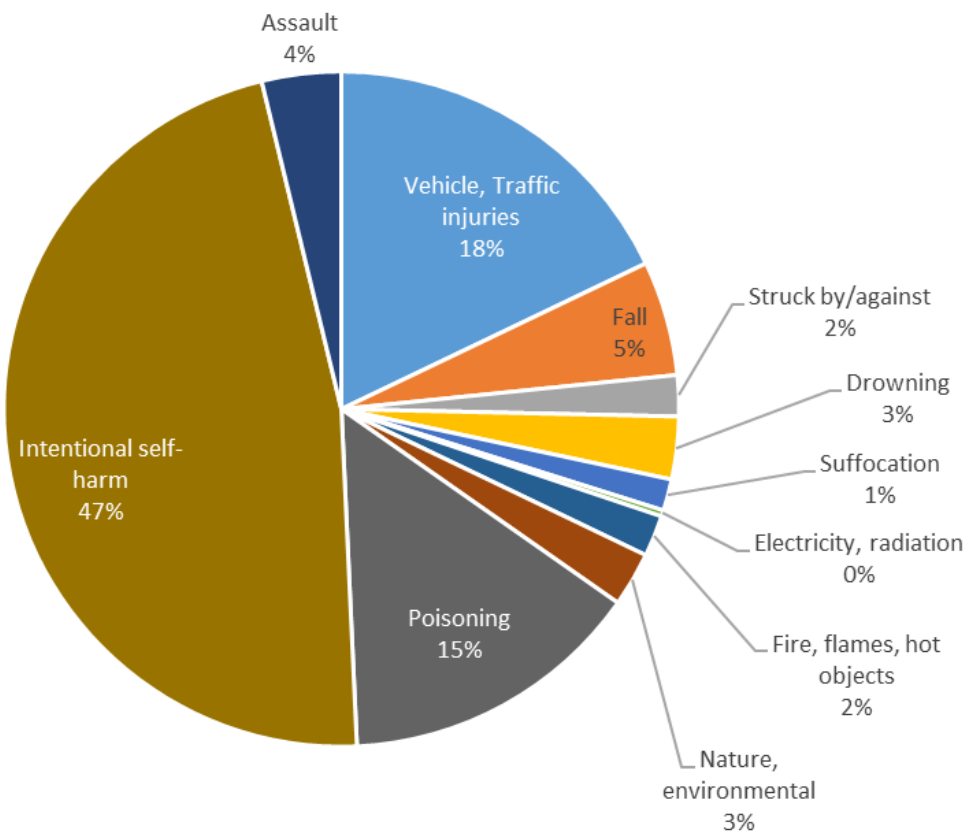




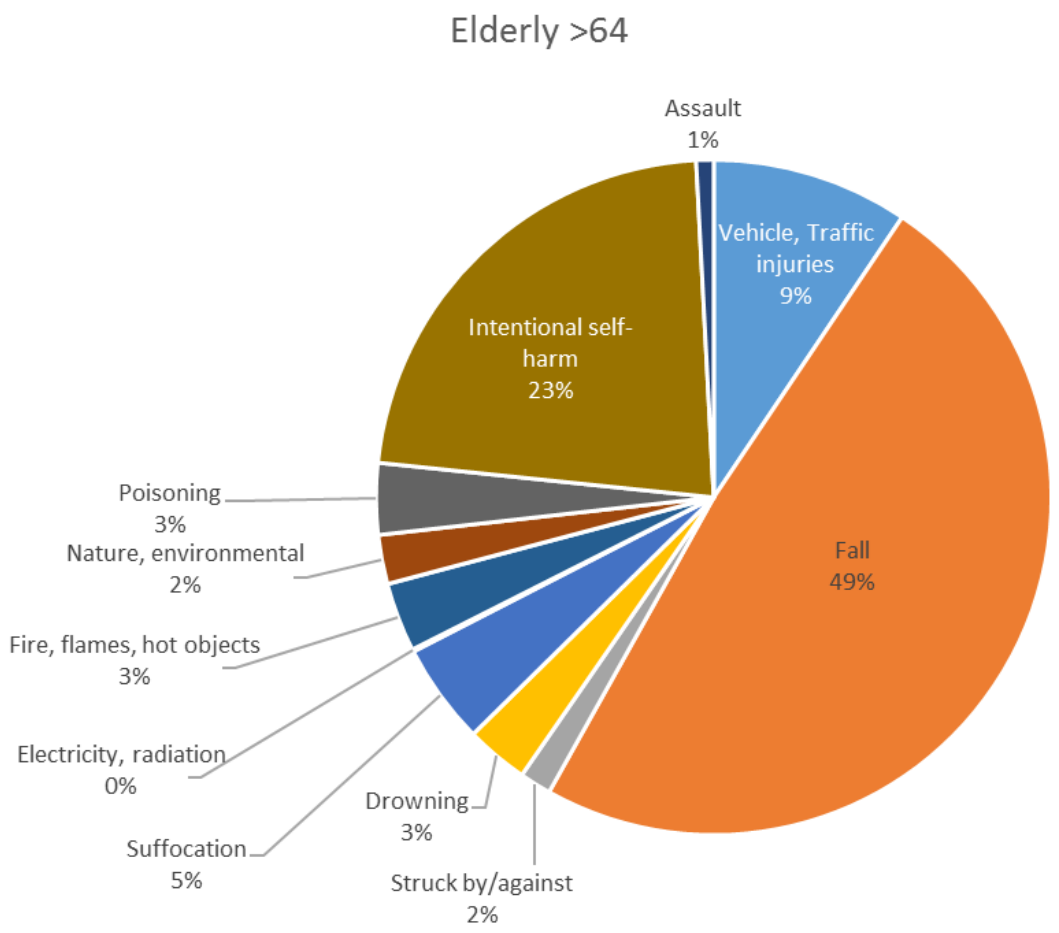

Fig. 6. The percentage of deaths in different injury mechanisms, calculated on the total number of deaths in each age group, children $n=1213$, working age $n=$ 25388 , and elderly $n=18332$.

\section{Injury related mortality changes depicted over time by injury mechanisms and age groups}

In the working age mortality declined for the following injuries: traffic related (coefficient $-0.34, \mathrm{r}^{2}=0.85 ; \mathrm{p}<0.001$ ), drowning (coefficient $-0.05, \mathrm{r}^{2}=0.58 ; \mathrm{p}=$ 0.002 ), and assault (coefficient $-0.03, \mathrm{r}^{2}=0.36 ; \mathrm{p}=0.022$ ). The only mechanism of injury for which mortality increased in this age group was poisoning (coefficient $0.23, \mathrm{r}^{2}=0.78 ; \mathrm{p}<0.001$ ).

In the elderly there were two mechanisms that lead to more deaths: fall (coefficient 1.71, $\mathrm{r}^{2}=0.84 ; \mathrm{p}<0.001$ ) and poisoning (coefficient $0.13, \mathrm{r}^{2}=0.69 ; \mathrm{p}$ $<0.001$ ). The following reasons decreased: traffic (coefficient $-0.41, \mathrm{r}^{2}=0.82 ; \mathrm{p}<$ 0.001 ), drowning (coefficient-0.10, $\mathrm{r}^{2}=0.50 ; \mathrm{p}=0.005$ ), suffocation (coefficient $-0.11, r^{2}=0.77 ; p<0.001$ ), fire, smoke, hot objects (coefficient $-0.08, r^{2}=0.29 ; p$ 
$=0.049$ ), self-harm (coefficient $-0.45, \mathrm{r}^{2}=0.75 ; \mathrm{p}<0.001$ ), and assault (coefficient $-0.05, r^{2}=0.50 ; p=0.005$ ). In the children there were too few cases to calculate mortality over time and for different injury mechanisms.

\section{Penetrating injuries}

There was a decline in the mortality caused by sharp objects (coefficient -0.02 , $r^{2}=0.41 ; p=0.008$ ) while there was no change over time in those killed by gunshots (coefficient -0.001, $\mathrm{r}^{2}=0.00 ; \mathrm{p}=0.89$ ) (Fig. 7).

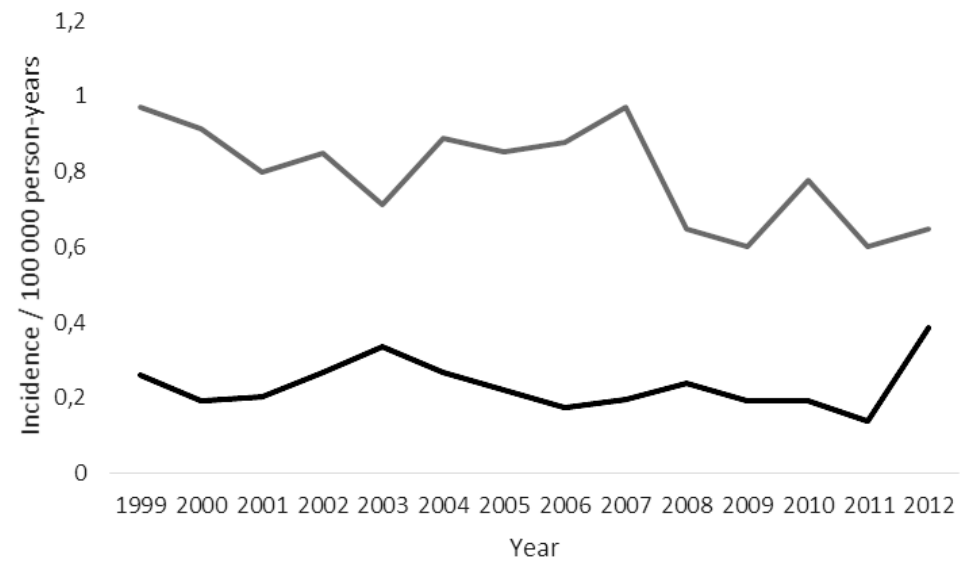

Fig. 7. Penetrating injuries. Black= Gunshots, Grey= Sharp objects

\section{The effect of intention on injury mortality}

Ninety seven percent of those who died because of penetrating trauma (sharp objects and firearms) were killed by intentional trauma (assault and intentional self-harm) Death caused by intentional trauma declined during the study period (coefficient -0.02, $\mathrm{r}^{2}=0.44 ; \mathrm{p}=0.01$ ) (Fig. 8). Unintentional and death with unknown intent were too few for an analysis.

Children deaths from unintentional injury was more common than that after intentional injury ( $\mathrm{p}<0.0001)$, the incidence being 1.4/100 000 children-years (95\% CI 1.3-1.5). There was a reduction in the incidence of unintentional injuries in children during the study period (coefficient $-0.13, \mathrm{r}^{2}=-0.52, \mathrm{p}=0.03$ ). The number of deaths after intentional injury increased between 1999 and 2012 (coefficient $0.04, \mathrm{r}^{2}=0.34, \mathrm{p}=0.03$ ) and at the end of the period it reached 1.5 deaths/100 000 children-years (95\% CI 1.0-2.1) (Fig. 9). 


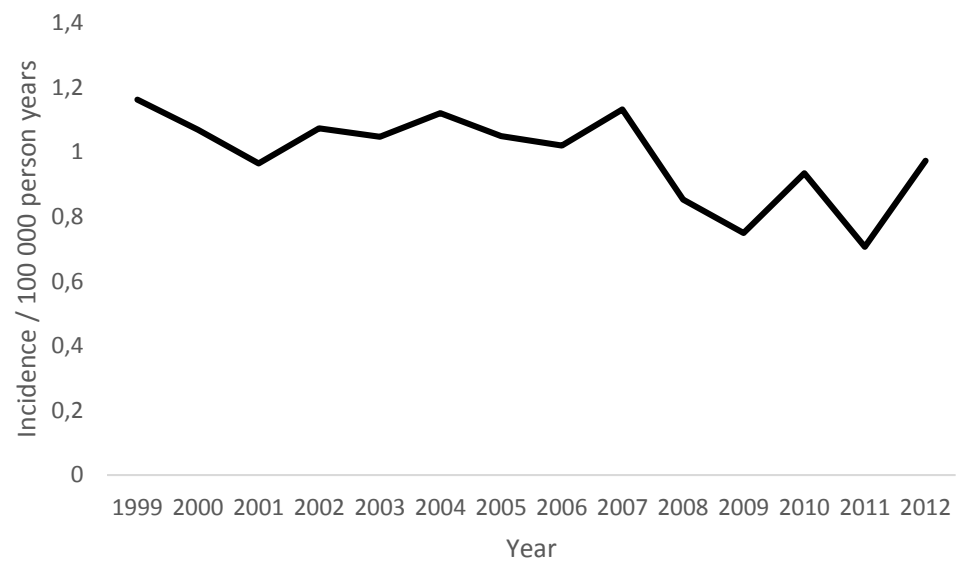

Fig. 8. Intentional injuries in penetrating injuries (sharp objects and firearms)

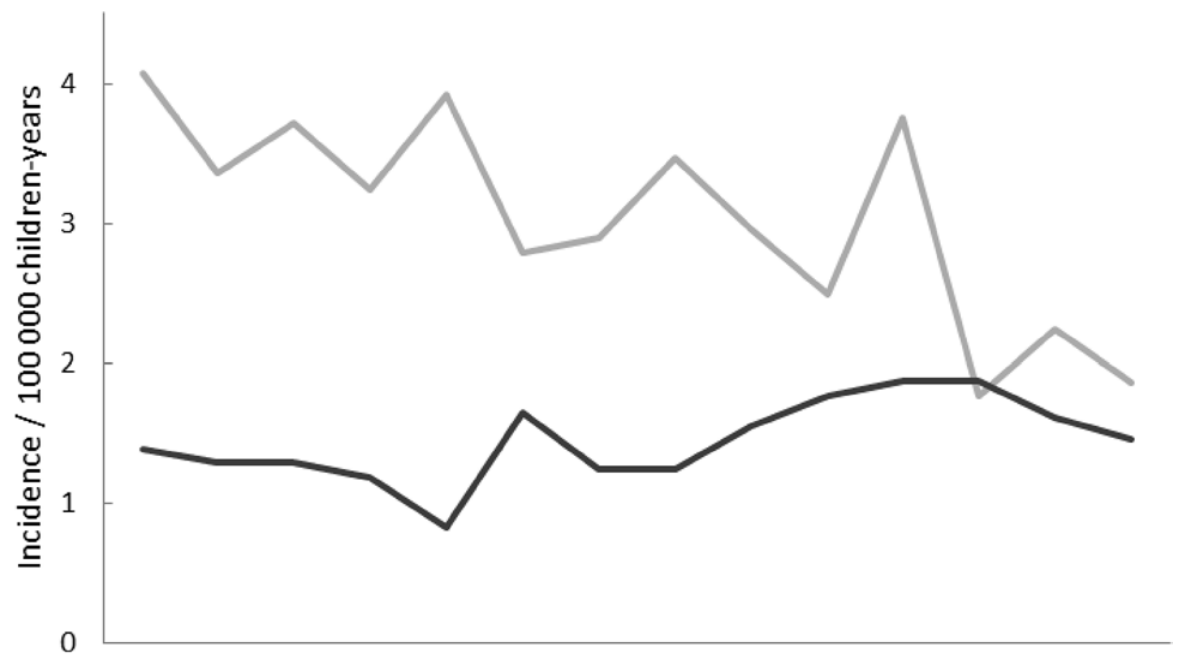

19992000200120022003200420052006200720082009201020112012

Fig. 9. Incidence of unintentional (grey) and intentional (black) injuries in children, years on X-axis

\section{Injury mortality and the effect of location (pre or in hospital)}

The crude overall in hospital mortality remained relatively stable over time (from 17 to 17 dead within 30 days/100 000 inhabitants, $p=0.72$ ). The incidence of fallrelated injuries treated in hospital decreased from 689 to 636 hospital admissions 
/ 100000 inhabitants ( $\mathrm{p}=0.047$, coefficient $-4.71,95 \%$ confidence interval (CI) 9.93 to 0.06 ), and traffic-incident-related ones from 169 to 123 observations/100 000 inhabitants, ( $\mathrm{p}<0.0001$, coefficient $-5.37,95 \%$ CI -6.91 to -3.82$)$. The incidence of assault-related injuries remained almost unchanged over the period (from 25 to 26 hospital admissions $/ 100000$ inhabitants, $\mathrm{p}=0.45$, coefficient $0.11,95 \% \mathrm{CI}$ 0.21 to 0.43 ).

The risk-adjusted 30-day mortality for patients treated in hospital decreased in traffic related injuries (OR 0.95; 95\% CI 0.93 to 0.97) and assault (OR 0.93; 95\% CI 0.87 to 0.99 ), while no change was seen in mortality after falls.

There was a small decline in the pre hospital incidence in deaths by penetrating injuries (coefficient $-0.02, \mathrm{r}^{2}=0.30 ; \mathrm{p}=0.04$ ) during the study period.

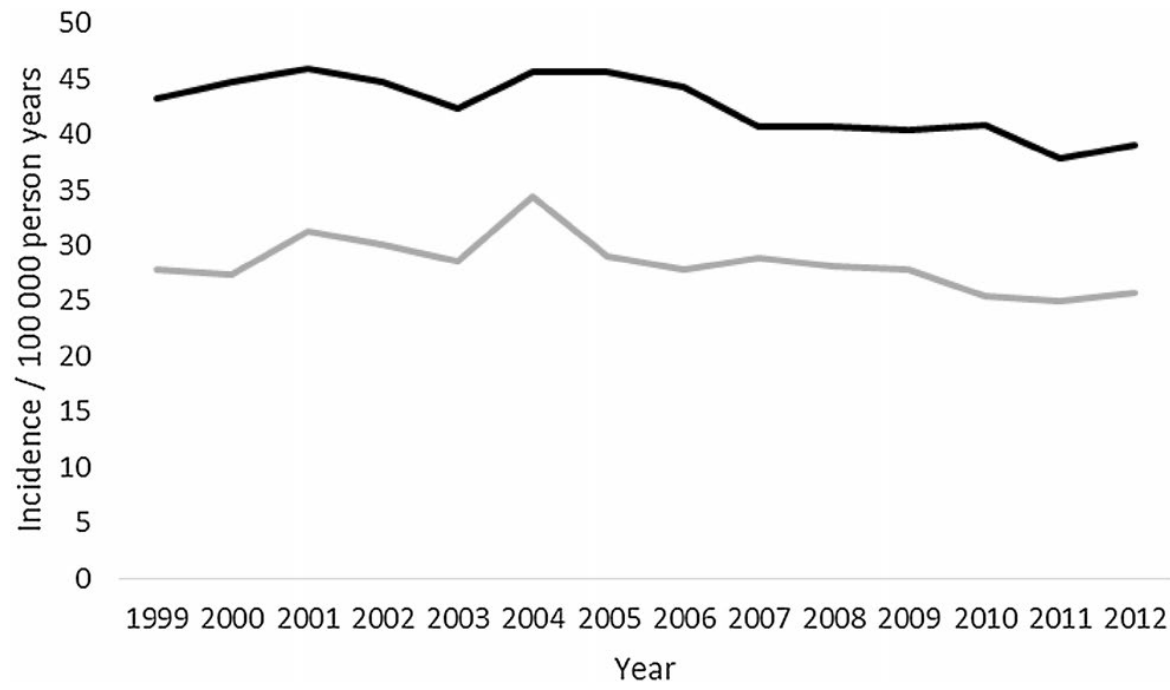

Fig. 10. Mortality before admission/100 000 by year. Black aged 65 and over, gray working age

One thousand and seventeen (83\%) of the children died prehospital. In the working age 22211 (80\%) of 25388 died pre hospital. Mortality in the working age declined overall, both in hospital (coefficient $-0.09, \mathrm{r}^{2}=0.60 ; \mathrm{p}=0.001$ ) and before admission (coefficient $-0.31, r^{2}=0.29 ; p=0.048$ ) (Fig. 10). Nine thousand six hundred and eighteen (53\%) of 18332 of the elderly died prehospital. Mortality before admission to hospital in the elderly decreased (coefficient -0.51 , $\mathrm{r}^{2}=0.63 ; \mathrm{p}=0.001$ ) (Fig 10), and that after admission to hospital increased (coefficient 1.10, $\mathrm{r}^{2}=0.73 ; \mathrm{p}<0.001$ ). 


\section{DISCUSSION}

The incidence of injury mortality in Sweden in this study was found similar to what others have reported in Scandinavia $(4,33,58)$. The injury mortality distribution we found is as expected dominated by blunt injuries in traffic accidents in the working age group and in falls in elderly. The intentional injuries which are dominated by intentional self-harm group has been shown before but by looking at it in different age-groups and over time we have been able show an increase in children that has not been noted before. We have also been able to show that the injury mechanism causing deaths has a different pattern in the working age as compared to elderly which should lead to an increased focus on the preventive work in these areas.

\section{Injury-related mortality in different age groups over time}

We were surprised to find that the overall injury mortality during the study period remained unchanged. Compared to what others have found in Scandinavia our incidence with 33 deaths / 100000 person years was in the lower range reported (4).

The increase in injury mortality in children starts in teenage years (Fig. 3). The higher mortality in older age has been described several times before $(25,28,29)$ but we can also show that injury mortality is increasing with older age in all agegroups (except for 15-25 and 25-35 years) not only in the very old (Fig. 1, Fig. 2).

\section{Children}

The decrease in child injury mortality in Sweden is interesting (Fig. 4) as Sweden already has one of the lowest childhood mortality rates in the European Union (21). This indicates that further reduction can be obtained in other countries too. The decline was more pronounced among the boys, which also is an interesting finding. We have not been able to find a specific reason for this decline but one explanation could be that child injury mortality in girls is already on very low level making it hard to lower it even further.

\section{Working age}

It was interesting to find a decline in mortality in the working age (Fig. 5). The working age is the largest age group $(24,25)$ and the overall unchanged mortality could mislead us to get the impression that nothing has changed in trauma mortality but this finding indicates that preventive work and improvements has had an effect although only in specific age groups. There are some publications 
presenting similar results, although those studies were done on more specific subgroups (59).

\section{Elderly}

It has been suggested that the age of 70 years should be used as a cut of for elderly people because of mortality inclining at that age (24). We chose the age of 65 as this is the age where most people retire in Sweden, and we think that retirement changes the way people behave in society and thus the risks they subject themselves to.

The downside of the decrease in injury mortality in the working age and the overall unchanged mortality is that there can be an incline in injury mortality in the group of elderly. The results of the present study, however, indicate that the increase is not merely an effect of an aging population (Fig. 5). This is interesting because it suggests that the preventive work and the improvements in healthcare has not been effective in the elderly. This issue has been addressed by others: one perspective is that coexisting morbidities in the group of elderly can result in higher level of severity of a given type of injury $(60,61)$; another is the need of targeted preventive measures (62); although some authors put forward that the overall knowledge about trauma related issues in the group of elderly is insufficient, and that the whole field, from prevention to rehabilitation, needs to be studied more closely (63).

\section{Injury mechanism}

We found an incidence in penetrating trauma (sharp objects and firearms) that was (Fig. 7) lower than what has been reported previously from Scandinavia (1). Fowler et al. (64) report a firearm mortality incidence of 10.2 / 100000 inhabitants in the united states which is almost ten times as high as that we found in Sweden (Fig. 7).This Scandinavian trauma pattern with few penetrating injuries is a known phenomenon and it contributes to the whole trauma picture with a higher mean age of the trauma victims and falls as one of the most common trauma mechanisms $(4,26,33)$.

\section{Children}

Traffic accidents was the most common trauma mechanism in children (Fig. 6), which is similar to what other have reported $(6,20,33,65)$. As the country has been urbanized children have been separated from the traffic through modern city planning with separate pedestrian and cycle lanes (38). During the study period the "Zero policy" implemented by "The Swedish transport administration" has been adopted and the aim is to develop a safe road transport system including information campaigns about child safety restraints, separated traffic lanes travelling in opposite directions and safer cars. Swimming lessons and the use of 
life-jackets have also paid off with a markedly decline in drownings since the 1950s (38).

\section{Working age}

The most common mechanism of injury among those of working age was selfharm, which was more than twice as common as injuries from vehicle and traffic collisions (Fig. 6). Kristiansen et al. (26) also found it to be the most common cause of death from injury in the working age population, although not quite to the same extent. Soreide et al. (33) reported that suicide was responsible for $21 \%$ of (54 of 269) the deaths, and another Norwegian study by Bakke et al. (40) found it to be $33 \%$ (87 of 266), which is close to the $37 \%$ that we found in adults (Table 1 ). In the working age group, self-harm was responsible for almost half of the deaths (Table 1).

The second most common cause of death among those of working age was injuries related to vehicle and traffic collisions. In 2002 the decrease in vehicle-related mortality seemed to have levelled off in Sweden (6), thus we did not expect to find a distinct decline during the whole period. Traffic-related injuries have been reported to be the most common cause of death from injury in Scandinavia in several studies $(33,47,65,66)$. Improvements in medical technology seem to have had an impact on this decline, and could be a contributing factor (59). During the period there have been several preventive measures taken under the "zero policy" strategy implemented by The Swedish Transport Administration. Our data support this as a good example of how preventive measures can affect mortality.

\section{Elderly}

As many others have shown before us the most common injury mechanism in elderly was fall $(25,28,29,58,67-69)$. We also found that fall is not a common cause of injury death in the working age. Looking at the whole population fall seems to be an important injury mechanism although with our study it is obvious that preventive measures should be focusing on the elderly. We also found an increase in incidence of falls in the elderly suggesting the need for further preventive measures.

\section{Intention}

Intentional self-harm is a major contributor to injury mortality $(33,40,70)$. The decline in intentional self-harm in penetrating injuries could in part be attributed to changing trends in suicide methods as there seems to be a changing trend over time $(71,72)$. We found intentional self-harm by handgun discharge in Sweden ( 0.19 per 100000 person years) to be in a totally different range than the 7.19 per 100000 that Fowler et al. (64) found in the United States. Homicides are also less 
frequent in our study ( 0.03 per 100000 person years) compared to the 3.66 per 100000 that Fowler et al. (64) found. Although there is a difference in the numbers there are some similarities, the most common cause of mortality by handguns is self-inflicted followed by assault in both the United States and Sweden (64). It has been showed that access to firearms contribute to suicides with firearms $(70,73)$. Self-harm injuries with firearms are known to be more lethal than other methods (71).

\section{Children}

Mortality patterns in injured children in Sweden have changed from being dominated by unintentional injuries to a more equal distribution between unintentional and intentional injuries. The overall rate has declined as has been found by others in the past and this decline results from a mortality reduction that is more pronounced among the boys. The increasing mortality after intentional injuries in our series was not as pronounced as the decrease in unintentional injuries. The distribution between the two in our series now seems to approach that in other parts of the world where mortality after injury among children has a more equal distribution, and unintentional injuries are only slightly more common (74), and intentional injuries show no signs of decreasing (75). Self-harm dominates in data from the intentional studies, and one reason why this group is increasing could be a change in coding policies in Sweden with perhaps a more liberal attitude towards reporting self-destructive behaviour.

\section{Location (pre or in hospital)}

\section{In hospital}

The incidence of fall and traffic related injuries treated in hospital decreased, but the same was not seen in assault injuries. There was a decrease in risk adjusted mortality for traffic and assault injuries treated in hospital, which may suggest that there have been improvements in prehospital and/or in-hospital management of these injuries. Risk adjusted mortality for fall related injuries treated in hospital did not decrease.

\section{Pre hospital}

There is no nationally organized system using physicians in pre-hospital care in Sweden. In some parts of the country there is a physician available at some hours but during the study period that was a rare phenomenon. There are some studies suggesting that pre-hospital physicians have an impact on trauma mortality (76, 77). The lack of prehospital physicians in Swedish medical care could contribute to the high numbers of prehospital deaths. Prehospital death rates are higher in rural areas $(5,26)$ which could also contribute to our findings as a majority of the Swedish population live in rural areas. 


\section{Children}

Injury death was more common pre hospital in children. With 83\% dying before reaching the hospital children are more likely to die pre hospital than the elderly but not than the working age group. The place of death (in or out of hospital) has been related to intent as those with intentional injuries are more likely to die outside the hospital (34), and our study also supports this.

\section{Working age}

We think that the high numbers of self-inflicted injuries in part also explains the high numbers of pre hospital deaths in the working age group population. Suicides have high prehospital death rates $(5,40)$ because of the mechanism of injury, i.e., that it is designed to be lethal. Injury related prehospital death has been reported to be in the range of between $45 \%$ and $85 \%$ in Scandinavia $(5,26,33,47,58,65)$. Wisborg et al. (47) found the highest number with 85\%, and Kristiansen et al. (26) who studied a working age population in Norway found a $78 \%$ overall prehospital mortality. Our finding of $87.5 \%$ pre-hospital deaths in the working age group is higher but the overall pre hospital mortality in adults was only $72 \%$ in our study.

\section{Elderly}

The number of pre hospital injury deaths is only 53\% in elderly which makes it almost as common to die in hospital as pre hospital in this group. Pre hospital mortality decreased while in hospital mortality increased. This could be a result of several different mechanisms. One being that pre hospital medical providers do better which results in a higher number of injured reaching hospitals alive. This could of course also be a result of an in hospital healthcare that has deteriorated over time.

\section{GENERALIZABILITY}

Sweden is a typical northern European country with cold weather and a mainly rural setting. The EMS and healthcare organisations have many similarities as well as the medical training programmes for health professionals (4). Because of this we think that our results are generalizable in northern Europe. We also think these results are important for other parts of the world as we can show the importance of both looking at the whole injury or trauma cohort and to analyse subgroups to better understand the injury epidemiology. According to our results it is clear that fall is an important injury mechanism, and when analysing different age groups it is clear that this mechanism is important especially in the elderly but less in children or the working age group. With this information preventive work can be targeted to this specific group and hopefully improve the mortality figures in future studies. 


\section{STRENGTHS AND LIMITATIONS}

In this work we have had an injury focus with an inclusive approach that we think is an advantageous when doing larger epidemiological studies. By including all injury diagnoses we can get a more complete overview of the injury and trauma picture in Sweden. Injury is a larger term which includes more diagnoses than trauma. Some diagnoses are defined as trauma but are usually excluded from trauma research, probably because they traditionally have not been included in trauma databases.

One of the strengths of this work is that a government-financed database that applies to every Swedish inhabitant was used, and thus this gives a complete picture without the risk of bias. The necropsy rate in this database was $79 \%$ of those who died of injuries before admission to hospital (34). A limitation of this work is the retrospective design, which requires that the physicians have filled in the death certificates correctly. The long study period (14 years) is a strength, as it allows the development of the picture over time and lowers the risk of drawing conclusions from a single deviant year. A strength, though, was that as we included all deaths from injury we were able to show that most died before admission to hospital, and that such deaths are decreasing over time. If they are excluded, important information about death from injury and the mechanisms involved would be lost, and conclusions would not be as solid. We think that our findings are important to enforce the preventive work that is being done in the society and in the organization of healthcare.

The Risk adjusted mortality analysis by ICISS on a large data set entails some challenges. The selection of valid cases in a data set too big for manual management is a challenging task. In addition, the relatively technically complicated method that ICISS is based on can complicate the interpretation and presentation of the results.

Miscoding of ICD-10 codes is a reality although it has shown to be below $40 \%$ in trauma studies $(78,79)$. The amount of miscoding vary between different studies and diseases (78-80). 


\section{FUTURE CHALLENGES}

Injury is a major contributor to death and morbidity worldwide, Sweden is no exception (6). Injury death has been lowered in Sweden by using a continuous systematic preventive work as well as the medical improvements that has been achieved in recent years. Sweden has a typical injury pattern that can be found in Scandinavia with a mainly blunt trauma mechanism, a male predominance and high numbers of pre hospital deaths. The decline in trauma mortality in Sweden can give important information about the effect of the preventive work and the medical improvements. Although Sweden already had the lowest numbers in child injury mortality in the world it has still been lowered further and this achievement should be studied further to be able to draw conclusions on how this was achieved.

Some areas of special concern is for example the incline in intentional self-harm in children that deserves to be studied further as this could potentially be an area that could benefit from preventive work. The incline in in hospital mortality in the elderly is also something that would be interesting to study. Penetrating trauma with very low numbers found in Sweden should be useful for other countries in lowering their numbers. The high numbers of pre hospital death needs to be further examined as it is potentially an area where many lives could be saved if the right interventions are implemented. 


\section{CONCLUSIONS}

- The overall injury mortality remains unchanged in Sweden but looking at different subgroups differences are registered, such as a decline in children (boys) and for the working age-group but in conjunction to an increase in the elderly.

- The fact that injury mechanism patterns varies between different age groups is important when planning preventive measures.

- Unintentional injuries in children has decreased while intentional injuries increases.

- Most of the penetrating injuries are intentional.

- Prehospital mortality is high in Sweden and a decrease is seen during the study period.

- The findings that in hospital risk adjusted mortality has been decreasing in traffic and assault related injuries but not in fall related injuries suggest that the medical treatment has been improved over time. The treatment policies and routines for the group of elderly requires further studies with subsequent actions however. 


\section{SUMMARY IN SWEDISH}

Bakgrund: Skador är en av de vanligaste dödsorsakerna världen över. Olika typer av skador dominerar på olika platser och har olika påverkan på mortaliteten. I Skandinavien dominerar skador av trubbigt våld och majoriteten dödsfallen sker utanför sjukhus. Över tid varierar olika skademönster och genom att analysera detta kan vi bedöma var och hur preventivt arbete kan förstärkas. Målet med den här avhandlingen var att studera skadeepidemiologi i Sverige och bedöma hur olika skademönster påverkar mortaliteten.

Metod: Vi använde det svenska dödsorsaksregistret och slutenvårdsregistret vilka har en komplett nationell täckning. ICISS beräknades (baserat på ICD-10) på sjukhus-populationen. Vi har valt att göra den här studien med ett brett perspektiv och använda termen skada, vilket inkluderar trauma men också andra diagnoser såsom kvävning eller drunkning.

Resultat: Under studieperioden (1999-2012) var antalet döda på grund av skada; 1213, 25388 och 18332 bland barn, arbetsför ålder och äldre. Mortaliteten sjönk bland barnen och i arbetsför ålder men steg i gruppen av äldre. Mortaliteten steg med varje åldersgrupp förutom mellan 15-25 och 26-35 år. Ettusentvåhundrasextiofyra (97\%) av dem som dog på grund av penetrerande skador (skärande föremål och skjutvapen) dog på grund av avsiktlig skada (överfall och självskador). Ettusen-sjutton (83\%) av barnen dog innan transport till sjukhus. I arbetsförålder dog 22211 (80\%) av de 25388 utanför sjukhus. Niotusensexhundraarton (53\%) av 18332 äldre dog utanför sjukhus. Under 2001-2011 sjönk den risk-justerade mortaliteten för dem som vårdats på sjukhus på grund av trafik och överfall men inte för fall-relaterade skador.

Diskussion: Överlag hittade vi den förväntade skadebilden, med skador efter trubbigt våld (trafikolyckor) som dominerar i arbetsför ålder och fall som dominerar hos äldre. En betydande andel av dem som dog gjorde det utanför sjukhus. De avsiktliga skadorna domineras av självskador. Minskningen av skademortaliteten bland barn är anmärkningsvärd eftersom Sverige redan har en av världens lägsta incidenser i världen. Minskningen i skademortalitet i arbetsför ålder antyder också att det preventiva arbetet haft en effekt. Ökningen i skademortalitet hos de äldre behöver å andra sidan studeras ytterligare. Intressanta områden för fortsatt preventivt arbete är den ökande skademortaliteten bland äldre och de ökningen av avsiktliga skador hos barn. 


\section{ACKNOWLEDGMENTS}

I would like to express my gratitude to everyone that supported me and contributed to this thesis. Friends, colleagues, co-workers, specifically I would like to thank the following:

My supervisor, Folke Sjöberg, for always being positive and seeing the glass as half full. For the valuable knowledge of the scientific process and how to master it.

My co-supervisor, Ingrid Steinvall, for being there and answering every question, often the same question over and over again. Your sense of details that has helped me in every step of the way.

My co-supervisor, Mats Fredrikson, for helping me understand what the numbers really represents.

Robert Larsen for the interesting discussions and valuable input in my scientific work.

Rolf Gedeborg for the valuable inputs in the research work.

Göran Liffner and Gustav Engström for teaching me how to manage injured patients as an anaesthesiologist.

My unit, The Life Regiment Hussars, K3, for helping me develop in the field of pre hospital trauma resuscitation.

The board in Svensk förening för läkare inom prehospital akutsjukvård (SFLPA) for the interesting discussions and the support.

My mother Anita Bäckström, for making me believe that I can do anything and for being the most loyal and caring supporter.

My husband Fredrik Bäckström, for being the solid foundation that help me grow.

My son Wilhelm Bäckström, for all the things you do for everyone else, you set an example for the rest of us.

My son Waldemar Bäckström, for being there for the rest of the family when I was working on my thesis. 
My son Widar Bäckström, for helping me understand how all the complicated things in the world works.

My daughter Ofelia Bäckström, for showing me that being strong and smart is the most natural thing in the world. 


\section{REFERENCES}

1. Eurosafe. Injuries in the European Union, report on injury statistics 20082010. Amsterdam, 2013.

2. Alberdi F, Garcia I, Atutxa L, Zabarte M, Trauma, Neurointensive Care Work Group of the S. Epidemiology of severe trauma. Medicina intensiva. 2014 Dec;38(9):580-8. PubMed PMID: 25241267.

3. Bakke HK, Dehli T, Wisborg T. Fatal injury caused by low-energy trauma a 10-year rural cohort. Acta anaesthesiologica Scandinavica. 2014 Jul;58(6):72632. PubMed PMID: 24773521. Pubmed Central PMCID: 4171781.

4. Kristiansen T, Soreide K, Ringdal KG, Rehn M, Kruger AJ, Reite A, et al. Trauma systems and early management of severe injuries in Scandinavia: review of the current state. Injury. 2010 May;41(5):444-52. PubMed PMID: 19540486.

5. Raatiniemi L, Steinvik T, Liisanantti J, Ohtonen P, Martikainen M, Alahuhta $\mathrm{S}$, et al. Fatal injuries in rural and urban areas in northern Finland: a 5-year retrospective study. Acta anaesthesiologica Scandinavica. 2016 May;60(5):66876. PubMed PMID: 26749577. Pubmed Central PMCID: 4849198.

6. Hasselberg M. Chapter 5.7: major public health problems - injuries. Scandinavian journal of public health Supplement. 2006 Jun;67:113-24. PubMed PMID: 16762904.

7. The Swedish Tax Agency. https://www.skatteverket.se/privat/folkbokforing/personnummerochsamordn ingsnummer.4.3810a01c150939e893f18c29.html Accessed October 09, 2017.

8. Ludvigsson JF, Otterblad-Olausson P, Pettersson BU, Ekbom A. The Swedish personal identity number: possibilities and pitfalls in healthcare and medical research. Eur J Epidemiol. 2009;24(11):659-67. PubMed PMID: 19504049. Pubmed Central PMCID: 2773709.

9. World Health Organisation. International Statistical Classification of Diseases and Related Health Problems. Vol 2, 10th ed. Malta; 2011

10. Baker SP, O'Neill B, Haddon W, Jr., Long WB. The injury severity score: a method for describing patients with multiple injuries and evaluating emergency care. The Journal of trauma. 1974 Mar;14(3):187-96. PubMed PMID: 4814394.

11. Osler T, Rutledge R, Deis J, Bedrick E. ICISS: an international classification of disease- 9 based injury severity score. J Trauma. 1996 Sep;41(3):380-6; discussion 6-8. PubMed PMID: 8810953.

12. Rutledge R, Osler T, Emery S, Kromhout-Schiro S. The end of the Injury Severity Score (ISS) and the Trauma and Injury Severity Score (TRISS): ICISS, an International Classification of Diseases, ninth revision-based prediction tool, 
outperforms both ISS and TRISS as predictors of trauma patient survival, hospital charges, and hospital length of stay. J Trauma. 1998 Jan;44(1):41-9. PubMed PMID: 9464748.

13. Stephenson S, Henley G, Harrison JE, Langley JD. Diagnosis based injury severity scaling: investigation of a method using Australian and New Zealand hospitalisations. Injury prevention : journal of the International Society for Child and Adolescent Injury Prevention. 2004 Dec;10(6):379-83. PubMed PMID: 15583261. Pubmed Central PMCID: 1730146.

14. Hollis S, Lecky F, Yates DW, Woodford M. The effect of pre-existing medical conditions and age on mortality after injury. The Journal of trauma. 2006 Nov;61(5):1255-60. PubMed PMID: 17099538.

15. Wutzler S, Maegele M, Marzi I, Spanholtz T, Wafaisade A, Lefering R, et al. Association of preexisting medical conditions with in-hospital mortality in multiple-trauma patients. Journal of the American College of Surgeons. 2009 Jul;209(1):75-81. PubMed PMID: 19651066.

16. Charlson ME, Pompei P, Ales KL, MacKenzie CR. A new method of classifying prognostic comorbidity in longitudinal studies: development and validation. Journal of chronic diseases. 1987;40(5):373-83. PubMed PMID: 3558716.

17. Christensen S, Johansen MB, Christiansen CF, Jensen R, Lemeshow S. Comparison of Charlson comorbidity index with SAPS and APACHE scores for prediction of mortality following intensive care. Clin Epidemiol. 2011;3:203-11. PubMed PMID: 21750629. Pubmed Central PMCID: 3130905. Epub 2011/07/14. eng.

18. Gabbe BJ, Magtengaard K, Hannaford AP, Cameron PA. Is the Charlson Comorbidity Index useful for predicting trauma outcomes? Academic emergency medicine : official journal of the Society for Academic Emergency Medicine. 2005 Apr;12(4):318-21. PubMed PMID: 15805322.

19. Peden M. World report on child injury prevention appeals to "Keep Kids Safe". Injury prevention : journal of the International Society for Child and Adolescent Injury Prevention. 2008 Dec;14(6):413-4. PubMed PMID: 19074252.

20. Suominen P, Kivioja A, Ohman J, Korpela R, Rintala R, Olkkola KT. Severe and fatal childhood trauma. Injury. 1998 Jul;29(6):425-30. PubMed PMID: 9813697.

21. Petridou ET, Kyllekidis S, Jeffrey S, Chishti P, Dessypris N, Stone DH. Unintentional injury mortality in the European Union: how many more lives could be saved? Scandinavian journal of public health. 2007;35(3):278-87. PubMed PMID: 17530550. 
22. Janson S. Från barnolycksfall till barns rätt till säkerhet och utveckling. Stockholm: Norstedts Tryckeri AB; 2003. pp 79-142.

23. Ekman R, Svanstrom L, Langberg B. Temporal trends, gender, and geographic distributions in child and youth injury rates in Sweden. Injury prevention : journal of the International Society for Child and Adolescent Injury Prevention. 2005 Feb;11(1):29-32. PubMed PMID: 15691986. Pubmed Central PMCID: 1730173.

24. Caterino JM, Valasek T, Werman HA. Identification of an age cutoff for increased mortality in patients with elderly trauma. The American journal of emergency medicine. 2010 Feb;28(2):151-8. PubMed PMID: 20159383.

25. Lehmann R, Beekley A, Casey L, Salim A, Martin M. The impact of advanced age on trauma triage decisions and outcomes: a statewide analysis. American journal of surgery. 2009 May;197(5):571-4; discussion 4-5. PubMed PMID: 19393350.

26. Kristiansen T, Lossius HM, Rehn M, Kristensen P, Gravseth HM, Roislien J, et al. Epidemiology of trauma: a population-based study of geographical risk factors for injury deaths in the working-age population of Norway. Injury. 2014 Jan;45(1):23-30. PubMed PMID: 23915491.

27. Fairfax LM, Hsee L, Civil I. An ageing trauma population: The Auckland experience. The New Zealand medical journal. 2015 May 15;128(1414):36-43. PubMed PMID: 26117389.

28. Kehoe A, Smith JE, Edwards A, Yates D, Lecky F. The changing face of major trauma in the UK. Emergency medicine journal : EMJ. 2015 Dec;32(12):911-5. PubMed PMID: 26598629. Pubmed Central PMCID: 4717354.

29. Labib N, Nouh T, Winocour S, Deckelbaum D, Banici L, Fata P, et al. Severely injured geriatric population: morbidity, mortality, and risk factors. The Journal of trauma. 2011 Dec;71(6):1908-14. PubMed PMID: 21537212.

30. Sauaia A, Moore FA, Moore EE, Moser KS, Brennan R, Read RA, et al. Epidemiology of trauma deaths: a reassessment. The Journal of trauma. 1995 Feb;38(2):185-93. PubMed PMID: 7869433.

31. Demetriades D, Kimbrell B, Salim A, Velmahos G, Rhee P, Preston C, et al. Trauma deaths in a mature urban trauma system: is "trimodal" distribution a valid concept? Journal of the American College of Surgeons. 2005 Sep;201(3):343-8. PubMed PMID: 16125066.

32. Pape-Kohler CI, Simanski C, Nienaber U, Lefering R. External factors and the incidence of severe trauma: time, date, season and moon. Injury. 2014 Oct;45 Suppl 3:S93-9. PubMed PMID: 25284243. 
33. Soreide K, Kruger AJ, Vardal AL, Ellingsen CL, Soreide E, Lossius HM. Epidemiology and contemporary patterns of trauma deaths: changing place, similar pace, older face. World journal of surgery. 2007 Nov;31(11):2092-103. PubMed PMID: 17899256.

34. Gedeborg R, Chen LH, Thiblin I, Byberg L, Melhus H, Michaelsson K, et al. Prehospital injury deaths--strengthening the case for prevention: nationwide cohort study. The journal of trauma and acute care surgery. 2012 Mar;72(3):765-72. PubMed PMID: 22491568.

35. Plugge E, Stewar-Brown S, Knight M, Fletcher L. Injury morbidity in 1864-year-olds: impact and risk factors. Journal of public health medicine. 2002 Mar;24(1):27-33. PubMed PMID: 11939379.

36. Soreide K, Kruger AJ, Ellingsen CL, Tjosevik KE. Pediatric trauma deaths are predominated by severe head injuries during spring and summer. Scandinavian journal of trauma, resuscitation and emergency medicine. 2009;17:3. PubMed PMID: 19161621. Pubmed Central PMCID: 2637226.

37. Suominen P, Baillie C, Kivioja A, Korpela R, Rintala R, Silfvast T, et al. Prehospital care and survival of pediatric patients with blunt trauma. Journal of pediatric surgery. 1998 Sep;33(9):1388-92. PubMed PMID: 9766360.

38. Jansson B, De Leon AP, Ahmed N, Jansson V. Why does Sweden have the lowest childhood injury mortality in the world? The roles of architecture and public pre-school services. Journal of public health policy. 2006 Jul;27(2):146-65. PubMed PMID: 16961194.

39. Burd RS, Jang TS, Nair SS. Evaluation of the relationship between mechanism of injury and outcome in pediatric trauma. The Journal of trauma. 2007 Apr;62(4):1004-14. PubMed PMID: 17426560. Pubmed Central PMCID: 4969570.

40. Bakke HK, Wisborg T. Rural high north: a high rate of fatal injury and prehospital death. World journal of surgery. 2011 Jul;35(7):1615-20. PubMed PMID: 21538190. Pubmed Central PMCID: 3140949.

41. Trunkey DD. Trauma. Accidental and intentional injuries account for more years of life lost in the U.S. than cancer and heart disease. Among the prescribed remedies are improved preventive efforts, speedier surgery and further research. Scientific American. 1983 Aug;249(2):28-35. PubMed PMID: 6623052.

42. Di Bartolomeo S, Sanson G, Michelutto V, Nardi G, Burba I, Francescutti C, et al. Epidemiology of major injury in the population of Friuli Venezia GiuliaItaly. Injury. 2004 Apr;35(4):391-400. PubMed PMID: 15037374.

43. Ugur M, Akkucuk S, Koca YS, Oruc C, Aydogan A, Kilic E, et al. Where should the damage control surgery be performed, at the nearest health center or 
at a fully equipped hospital? Ulusal travma ve acil cerrahi dergisi $=$ Turkish journal of trauma \& emergency surgery : TJTES. 2016 May;22(3):273-7. PubMed PMID: 27598593.

44. Zafar SN, Haider AH, Stevens KA, Ray-Mazumder N, Kisat MT, Schneider EB, et al. Increased mortality associated with EMS transport of gunshot wound victims when compared to private vehicle transport. Injury. 2014 Sep;45(9):1320-6. PubMed PMID: 24957424.

45. Sollid S, Munch-Ellingsen J, Gilbert M, Ingebrigtsen T. Pre- and interhospital transport of severely head-injured patients in rural Northern Norway. Journal of neurotrauma. 2003 Mar;20(3):309-14. PubMed PMID: 12820685.

46. Peek-Asa C, Zwerling C, Stallones L. Acute traumatic injuries in rural populations. American journal of public health. 2004 0ct;94(10):1689-93. PubMed PMID: 15451733. Pubmed Central PMCID: 1448517.

47. Wisborg T, Hoylo T, Siem G. Death after injury in rural Norway: high rate of mortality and prehospital death. Acta anaesthesiologica Scandinavica. 2003 Feb;47(2):153-6. PubMed PMID: 12631043.

48. SOS Alarm. https://www.sosalarm.se/sprak/svenska/ Accessed October $07,2017$.

49. SFAI. Where should the damage control surgery be performed, at the nearest health center or at a fully equipped hospital Accessed October 22, 2017.

50. Handolin L, Leppaniemi A, Vihtonen K, Lakovaara M, Lindahl J. Finnish Trauma Audit 2004: current state of trauma management in Finnish hospitals. Injury. 2006 Jul;37(7):622-5. PubMed PMID: 16769310.

51. ten Duis HJ, van der Werken C. Trauma care systems in The Netherlands. Injury. 2003 Sep;34(9):722-7. PubMed PMID: 12951300.

52. American College of Surgeons. https://www.facs.org/qualityprograms/trauma/atls/about Accessed October 22, 2017.

53. ATLS Sverige. http://www.atls.se/ATLS/OmATLS/tabid/54/Default.aspx Accessed October 06, 2017.

54. PHTLS Sverige. http://www.phtls.se/?page id=31 Accessed October 07, 2017.

55. The National Board of Health and Wellfare.

http://www.socialstyrelsen.se/statistics/statisticaldatabase/help/causeofdeath Accessed October 10, 2017. 
56. The National Board of Health and Welfare.

http://www.socialstyrelsen.se/register/halsodataregister/patientregistret/inen glish Accessed October 10, 2017.

57. Statistics Sweden. Population by region, marital status, age and sex. Accessed March 14 2015. Available from: http://www.statistikdatabasen.scb.se/.

58. Meisler R, Thomsen AB, Theilade $\mathrm{P}$, Abildstrom $\mathrm{H}$, Borge $\mathrm{P}$, Treschow $\mathrm{M}$, et al. Age-related differences in mechanism, cause, and location of trauma deaths. Minerva anestesiologica. 2011 Jun;77(6):592-7. PubMed PMID: 21617622.

59. Noland RB, Quddus MA. Improvements in medical care and technology and reductions in traffic-related fatalities in Great Britain. Accident; analysis and prevention. 2004 Jan;36(1):103-13. PubMed PMID: 14572832.

60. Cartagena LJ, Kang A, Munnangi S, Jordan A, Nweze IC, Sasthakonar V, et al. Risk factors associated with in-hospital mortality in elderly patients admitted to a regional trauma center after sustaining a fall. Aging clinical and experimental research. 2017 Jun;29(3):427-33. PubMed PMID: 27142683.

61. DeBoard ZM, Grotts J, Ferrigno L. Outcomes of Recreational ActivityAssociated Trauma in Elderly Persons on Blood-Thinning Medications. The American surgeon. 2017 Apr 01;83(4):371-6. PubMed PMID: 28424132.

62. Hanba C, Gupta A, Svider PF, Folbe AJ, Eloy JA, Zuliani GF, et al. Forgetful but not forgotten: Bathroom-related craniofacial trauma among the elderly. The Laryngoscope. 2017 Apr;127(4):820-7. PubMed PMID: 27411519.

63. Jeschke MG, Peck MD. Burn Care of the Elderly. Journal of burn care \& research : official publication of the American Burn Association. 2017 May/Jun;38(3):e625-e8. PubMed PMID: 28362655. Pubmed Central PMCID: 5416819.

64. Fowler KA, Dahlberg LL, Haileyesus T, Annest JL. Firearm injuries in the United States. Preventive medicine. 2015 Oct;79:5-14. PubMed PMID: 26116133. Pubmed Central PMCID: 4700838.

65. Hansen KS, Morild I, Engesaeter LB, Viste A. Epidemiology of severely and fatally injured patients in western part of Norway. Scandinavian journal of surgery : SJS : official organ for the Finnish Surgical Society and the Scandinavian Surgical Society. 2004;93(3):198-203. PubMed PMID: 15544074.

66. Brattstrom O, Eriksson M, Larsson E, Oldner A. Socio-economic status and co-morbidity as risk factors for trauma. European journal of epidemiology. 2015 Feb;30(2):151-7. PubMed PMID: 25377535.

67. Rau CS, Lin TS, Wu SC, Yang JC, Hsu SY, Cho TY, et al. Geriatric hospitalizations in fall-related injuries. Scandinavian journal of trauma, 
resuscitation and emergency medicine. 2014;22:63. PubMed PMID: 25388273. Pubmed Central PMCID: 4232632.

68. Sjogren H, Bjornstig U. Unintentional injuries among elderly people: incidence, causes, severity, and costs. Accident; analysis and prevention. 1989 Jun;21(3):233-42. PubMed PMID: 2736020.

69. Saveman BI, Bjornstig U. Unintentional injuries among older adults in northern Sweden--a one-year population-based study. Scandinavian journal of caring sciences. 2011 Mar;25(1):185-93. PubMed PMID: 20626698.

70. Backstrom D, Larsen R, Steinvall I, Fredrikson M, Gedeborg R, Sjoberg F. Deaths caused by injury among people of working age (18-64) are decreasing, while those among older people (64+) are increasing. European journal of trauma and emergency surgery : official publication of the European Trauma Society. 2017 Aug 20. PubMed PMID: 28825159.

71. Large MM, Nielssen OB. Suicide in Australia: meta-analysis of rates and methods of suicide between 1988 and 2007. The Medical journal of Australia. 2010 Apr 19;192(8):432-7. PubMed PMID: 20402605.

72. De Leo D, Dwyer J, Firman D, Neulinger K. Trends in hanging and firearm suicide rates in Australia: substitution of method? Suicide \& life-threatening behavior. 2003 Summer;33(2):151-64. PubMed PMID: 12882416.

73. Miller M, Azrael D, Hemenway D. Firearm availability and suicide, homicide, and unintentional firearm deaths among women. Journal of urban health : bulletin of the New York Academy of Medicine. 2002 Mar;79(1):26-38. PubMed PMID: 11937613. Pubmed Central PMCID: 3456383.

74. Ortega HW, Velden HV, Krause E, Reid S. Traumatic deaths in children: is there a difference between urban and rural populations? Pediatric emergency care. 2013 Jan;29(1):36-8. PubMed PMID: 23283260.

75. Roberts I, Li L, Barker M. Trends in intentional injury deaths in children and teenagers (1980-1995). Journal of public health medicine. 1998 Dec;20(4):463-6. PubMed PMID: 9923955.

76. Taylor C, Jan S, Curtis K, Tzannes A, Li Q, Palmer C, et al. The costeffectiveness of physician staffed Helicopter Emergency Medical Service (HEMS) transport to a major trauma centre in NSW, Australia. Injury. 2012 Nov;43(11):1843-9. PubMed PMID: 22898559.

77. Ringburg AN, Polinder S, Meulman TJ, Steyerberg EW, van Lieshout EM, Patka $\mathrm{P}$, et al. Cost-effectiveness and quality-of-life analysis of physician-staffed helicopter emergency medical services. The British journal of surgery. 2009 Nov;96(11):1365-70. PubMed PMID: 19847879. 
78. Karkhaneh M, Hagel BE, Couperthwaite A, Saunders LD, Voaklander DC, Rowe BH. Emergency department coding of bicycle and pedestrian injuries during the transition from ICD-9 to ICD-10. Injury prevention : journal of the International Society for Child and Adolescent Injury Prevention. 2012 Apr;18(2):88-93. PubMed PMID: 21705466. Pubmed Central PMCID: 3313444.

79. Henderson T, Shepheard J, Sundararajan V. Quality of diagnosis and procedure coding in ICD-10 administrative data. Medical care. 2006 Nov;44(11):1011-9. PubMed PMID: 17063133.

80. Sanfilippo KM, Wang TF, Gage BF, Liu W, Carson KR. Improving accuracy of International Classification of Diseases codes for venous thromboembolism in administrative data. Thrombosis research. 2015 Apr;135(4):616-20. PubMed PMID: 25613924. Pubmed Central PMCID: 4361236. 


\section{Papers}

The papers associated with this thesis have been removed for copyright reasons. For more details about these see:

http:// urn.kb.se/ resolve?urn=urn:nbn:se:liu:diva-142762 